\title{
Notas, novos registros e novas espécies de Ibidionini (Coleoptera, Cerambycidae)
}

\author{
Ubirajara R. Martins ${ }^{1,3}$ \& Maria Helena M. Galileo ${ }^{2,3}$
}

\begin{abstract}
${ }^{1}$ Museu de Zoologia, Universidade de São Paulo, Caixa Postal 42594, 04218-970 São Paulo-SP, Brasil. urmsouza@usp.br ${ }^{2}$ Museu de Ciências Naturais, Fundação Zoobotânica do Rio Grande do Sul. Caixa Postal 1188, 90001-970 Porto Alegre-RS, Brasil. galileo@fzb.rs.gov.br ${ }^{3}$ Pesquisador do CNPq.
\end{abstract}

\begin{abstract}
Notes, new records and new species of Ibidionini (Coleoptera, Cerambycidae). New species are described from Brazil: Tropidion terminatum sp. nov. and Tropidion una sp. nov. (Rondônia); Tropidion buriti sp. nov. (Piauí); Compsibidion manauara, sp. nov. (Amazonas); Compsibidion elianae sp. nov. (Goiás); Compsibidion novalimae sp. nov. and Compsibidion peti sp. nov. (Minas Gerais); from Brazil (Mato Grosso) and Bolivia (Santa Cruz), Compsibidion ybyra sp. nov.; from Venezuela (Guarico), Tropidion jolyi sp. nov.; from Bolivia (Santa Cruz), Dodecaibidion bolivianum sp. nov. and Pygmodeon maculatum sp. nov. Minibidion captiosus nom. nov. to Minibidion bicolor Martins, Galileo \& Limeira-de Oliveira, 2011 is proposed. New status is presented for Compsibidion rubricolle Melzer, 1935 and notes on Heterachthes tysiphonis (Thomson, 1867) are presented. New records are presented for Tropidion zonapterum (Martins, 1962), Compsibidion campestre (Gounelle, 1908) and Kolonibidion femoratum (Martins, 1971).
\end{abstract}

KEYWORDS. Compsibidion; Heterachthes; Kolonibidion; Minibidion; Neotropical; Tropidion.

RESUMO. Notas, novos registros e novas espécies de Ibidionini (Coleoptera, Cerambycidae). Novas espécies descritas do Brasil: Tropidion terminatum sp. nov. e Tropidion una sp. nov. (Rondônia); Tropidion buriti sp. nov. (Piauí); Compsibidion manauara sp. nov. (Manaus), Compsibidion elianae sp. nov. (Goiás); Compsibidion novalimae sp. nov. e Compsibidion peti sp. nov. (Minas Gerais). Do Brasil (Mato Grosso) e da Bolívia (Santa Cruz), Compsibidion ybyra sp. nov.; da Venezuela (Guarico), Tropidion jolyi sp. nov.; da Bolívia (Santa Cruz), Dodecaibidion bolivianum sp. nov. e Pygmodeon maculatum sp. nov. Minibidion captiosus nom. nov. é proposto para Minibidion bicolor Martins, Galileo \& Limeira-de Oliveira, 2011. São estabelecidos novo status para Compsibidion rubricolle Melzer, 1935, e notas sobre Heterachthes tysiphonis (Thomson, 1867). São apresentados novos registros para Tropidion zonapterum (Martins, 1962), Compsibidion campestre (Gounelle, 1908) e Kolonibidion femoratum (Martins, 1971).

PALAVRAS-CHAVE. Compsibidion; Heterachthes; Kolonibidion; Minibidion; Neotropical; Tropidion.

Ao longo destes últimos anos temos recebido abundante material de Ibidionini para identificar. Algumas espécies contidas nesse material são inéditas e descritas a seguir. A tribo Ibidionini, no conceito original, foi dividida em Hexoplonini para os gêneros da então Divisão I (Martins 2006) e Ibidionini para as divisões III, IV e V. Por sua vez, Ibidionini foi dividida em três subtribos: Ibidionina, Tropidina e Compsina (Martins \& Galileo in Martins 2007).

$\mathrm{O}$ material estudado pertence às seguintes instituições: American Coleoptera Museum, San Antonio (ACMS); Carnegie Museum of Natural History, Pittsburgh (CMNH); Departamento de Zoologia, Universidade Federal do Paraná, Curitiba (DZUP); Instituto Nacional de Pesquisas da Amazônia, Manaus (INPA); Museo del Instituto de Zoologia Agrícola Francisco Fernández Yépez, Maracay (MIZA); Museu Noel Kempff Mercado, Santa Cruz (MNKM); Museu Nacional, Universidade Federal do Rio de Janeiro (MNRJ); Museu de Zoologia, Universidade de São Paulo (MZSP).

\section{Tropidion terminatum sp. nov.}

(Fig. 1)

Etimologia. Latim, terminatum $=$ limite, alusivo à extremidade dos élitros.
Cabeça preta, opaca, densamente microesculturada. Fronte com superfície irregular e alguns pontos rasos e esparsos. Lobos oculares superiores com quatro fileiras de omatídios. Antenas (macho) atingem as extremidades elitrais no terço apical do antenômero VI. Escapo piriforme, castanhoavermelhado. Pedicelo e flagelômeros avermelhados. Antenômeros III-X com comprimentos subiguais; XI um terço mais longo que o precedente.

Protórax preto. Pronoto com aspecto opaco, microesculturado $(30 \mathrm{x})$; pronoto com cinco gibosidades apenas indicadas; pubescência (visível conforme a incidência da luz) reveste a base e os lados da base até antes do meio; pontuação inexistente. Partes laterais do protórax sem pubescência. Prosterno com pubescência na metade posterior. Mesepisternos e mesepimeros preto-avermelhados. Restante da face ventral avermelhada; lados do metasterno com pubescência. Escutelo preto coberto por pubescência acinzentada.

Élitros pretos nos três quartos anteriores e amarelados no quarto apical; pelos curtos organizados em três fileiras longitudinais, dorsais; extremidades cortadas em curva com espinho externo.

Fêmures avermelhados; meso- e metafêmures pubescentes na face dorsal com abas apicais projetadas. Tíbias e tarsos avermelhados. 
Urosternitos avermelhados; os basais com pubescência.

Dimensões em mm, holótipo macho. Comprimento total, 8,7; comprimento do protórax, 2,0; maior largura do protórax, 1,6; comprimento do élitro, 5,8; largura umeral, 2,0.

Material-tipo. Holótipo macho, BRASIL, Rondônia: Ariquemes (62 km SW, near Fazenda Rancho Grande), 8-20.XI.1994, J. B. Eger, "blacklight trap" (MZSP).

Discussão. Tropidion terminatum sp. nov. caracteriza-se pelo colorido dos élitros que é único. Poderia ser comparado com T. elegans (Gounelle, 1908) que tem as faixas de pubescência do pronoto organizadas em duas faixas laterais da base ao meio. Em T. terminatum, a pubescência do pronoto reveste a base e os lados até antes do meio.

\section{Tropidion buriti sp. nov.}

(Fig. 2)

Etimologia. O nome é alusivo à localidade-tipo que, em tupi, é o nome de uma palmeira.

Cabeça castanho-avermelhada. Fronte microesculturada na metade superior com pontos escassos e pubescência muito esparsa, restrito ao lado interno dos tubérculos anteníferos. Vértice com microescultura entre os tubérculos anteníferos e os lobos oculares superiores, sem pubescência, com pontos rasos e numerosos (40x). Lobos oculares superiores com quatro fileiras de omatídios.

Antenas (fêmea) alcançam os ápices dos élitros, aproximadamente, no meio do antenômero VIII. Escapo avermelhado acentuadamente piriforme. Antenômeros III-XI alaranjados.

Protórax castanho-avermelhado. Pronoto glabro com cinco gibosidades apenas indicadas, microesculturado com pontos grandes (45x) e profundos, providos de pelos esbranquiçados. Partes laterais do protórax brilhantes. Prosterno com faixa estreita de pubescência a cada lado, da base ao meio.

Élitros com a base avermelhada e amarelados e translúcidos no restante da superfície; uma faixa avermelhada, curva, pouco aparente, no meio. Essa faixa parece limitar, na metade basal, grande mancha amarelada. Cada um com quatro linhas de pelos, três dorsais e uma lateral; extremidades obliquamente truncadas.

Fêmures avermelhados com ápice preto. Tíbias e tarsos amarelados. Face ventral do corpo avermelhada.

Dimensões em mm, holótipo fêmea. Comprimento total, 8,0; comprimento do protórax, 1,6; maior largura do protórax, 1,2; comprimento do élitro, 5,5; largura umeral, 1,8.

Material-tipo. Holótipo fêmea, BRASIL, Piaui: Canto do Buriti, 1822.XI.1991, C. R. F. Brandão col. (MZSP).

Discussão. Os élitros de Tropidion buriti sp. nov. são amarelados e translúcidos em grande extensão e apresentam base e faixa curva, pouco aparentes, avermelhadas. Esse colorido sugere que os élitros apresentam grande mancha amarelada que ocupa quase toda a metade anterior, mais avermelhada na sutura e no meio do élitro; toda metade apical é amarelada e translúcida, reticulada por transparência. Cada élitro com quatro fileiras longitudinais de pontos pilíferos.

Tropidion xanthocele (Martins, 1962), de Goiás e de Mato Grosso, também tem aspecto geral muito semelhante, com élitros amarelados, translúcidos, desarmados na extremidade; face ventral do corpo avermelhada e fêmures com ápice preto. Em T. xanthocele, contudo, o pronoto apresenta cinco tubérculos bem visíveis, os élitros não apresentam vestígio de áreas avermelhadas e cada élitro tem cinco fileiras longitudinais de pontos pilíferos.

\section{Tropidion jolyi sp. nov.} (Fig. 3)

Etimologia. O nome específico é uma homenagem a Luiz José Joly (MIZA) de Maracay, Venezuela.

Cabeça avermelhada. Fronte (40x) glabra, com microescultura fina e pontos rasos principalmente no lado interno dos tubérculos anteníferos. Vértice com pontos rasos na parte posterior. Lobos oculares superiores com quatro fileiras de omatídios. Antenas (macho) atingem as extremidades dos élitros no ápice do antenômero VI. Escapo castanho-avermelhado e escurecido na base; não é acentuadamente piriforme, mais para piriforme alongado, com sulco no lado dorsal de base. Antenômero III vermelho-escuro, sem carenas nítidas.

Protórax avermelhado. Pronoto glabro, liso; dois tubérculos arredondados no topo a cada um dos lados da base; vestígios de tubérculos ântero-laterais e central. Partes laterais do protórax lisas e brilhantes. Prosterno com pubescência em "V" na metade basal. Escutelo revestido por pubescência esbranquiçada.

Élitros amarelados; mancha circum-escutelar castanhoavermelhada prolongada pela sutura até o quarto anterior; frisos sutural e marginal e os espinhos apicais castanho-avermelhados. Pelos curtos organizados em três fileiras dorsais por élitro. Extremidades elitrais com espinho curto externo.

Fêmures avermelhados com ápices discretamente mais escurecidos. Aba externa dos metafêmures ligeiramente mais projetada. Tíbias castanho-avermelhadas. Metatíbias carenadas externamente. Tarsos avermelhados.

Face ventral avermelhada e pubescente.

Dimensões mm, holótipo macho. Comprimento total, 9,5; comprimento do protórax, 2,2; maior largura do protórax, 1,5; comprimento do élitro, 6,3; largura umeral, 1,9.

Material-tipo. Holótipo macho, VENEZUELA, Guarico: Mesa de Paya, 12.V.1955, J. Logiodice col. (MIZA).

Discussão. Tropidion jolyi sp. nov. não tem antenômero III carenado e o pronoto tem duas gibosidades nos lados da base, caracteres que a afastam um pouco do gênero. Entretanto, o escapo piriforme-alongado com sulco no lado superior da base e as cavidades coxais anteriores abertas atrás aconselham sua inclusão em Tropidion.

Pela chave publicada por Martins \& Galileo in Martins (2007), T. jolyi pode ser discriminada no item 36 com $T$. 

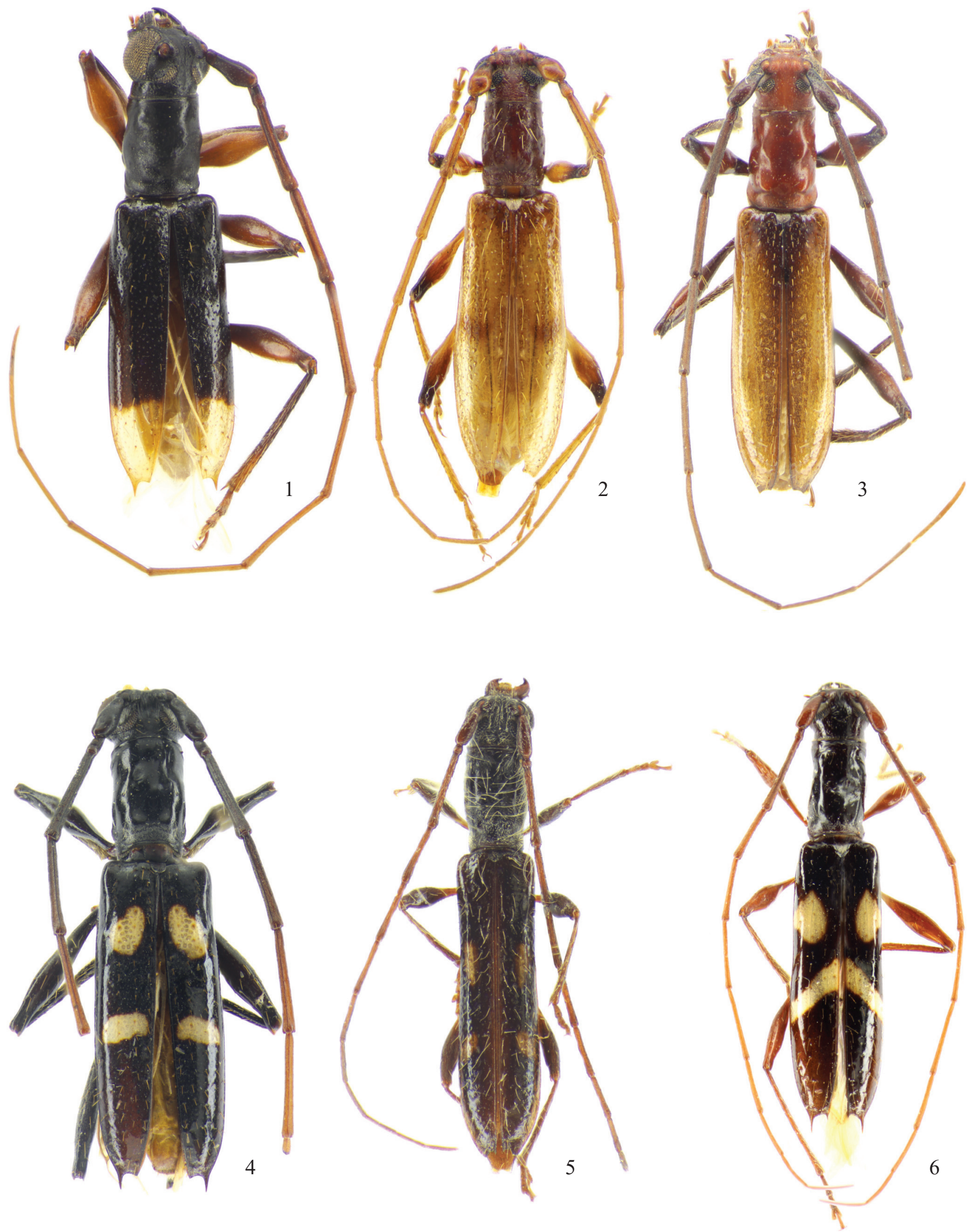

Figs. 1-6. 1. Tropidion terminatum sp. nov., holótipo macho, comprimento, $8,7 \mathrm{~mm} ; 2$. Tropidion buriti sp. nov., holótipo fêmea, comprimento total, 8,0 $\mathrm{mm}$; 3. Tropidion jolyi sp. nov., holótipo macho, comprimento, $9,5 \mathrm{~mm}$; 4. Tropidion una sp. nov., holótipo macho, comprimento, 10,4 mm; 5. Dodecaibidion bolivianum sp. nov., holótipo fêmea, comprimento, 7,0 mm; 6. Pygmodeon maculatum sp. nov., holótipo fêmea, comprimento, 11,8 mm. 
atricolle (Martins, 1962) e T. periboeoides (Thomson, 1867) pela cabeça avermelhada e ápices elitrais com pequena porção preta. Ambas as espécies são da Mata Atlântica do Brasil e têm os cinco tubérculos do pronoto bem marcados e não tem mancha castanho-avermelhada na base dos élitros.

\section{Tropidion una sp. nov.}

(Fig. 4)

Etimologia. Tupi, una = preto, alusivo à coloração predominante do corpo.

Macho. Cabeça preta. Fronte com fóveas laterais bem marcadas que delimitam com a carena fronto-clipeal área elíptica na metade inferior; metade superior pontuada; pubescência ausente. Vértice com microescultura (40 x) e raros pontos. Tubérculos anteníferos projetados, aguçados. Lobos oculares superiores com três fileiras de omatídios.

Antenas pretas na base e avermelhadas a partir do antenômero III atingem as extremidades dos élitros na base do antenômero VII. Escapo piriforme-alongado, com sulco no lado superior da base, sem pubescência e com pontos muito rasos, esparsos. Antenômero III carenado no lado interno e sulcado longitudinalmente no meio; comprimento apenas mais longo do que o seguinte. As antenas estão quebradas no ápice do antenômero VI.

Protórax preto. Pronoto com cinco gibosidades; a central mais projetada; pubescência numa faixa transversal que reveste o adelgaçamento basal; pontuação praticamente inexistente. Partes laterais do protórax lisas e brilhantes. Prosterno com pubescência em "V" na metade basal.

Escutelo com pubescência na borda apical. Élitros pretos; cada um com duas manchas branco-amareladas: uma no meio da metade anterior, arredondada, dorsal, não toca a margem nem a sutura; outra, pouco atrás do meio, transversal, mais próxima da sutura do que da margem; contam-se, no meio de cada élitro, cinco fileiras longitudinais de pontos pilíferos, quatro dorsais e uma lateral pouco evidente; pontuação praticamente restrita aos pontos pilíferos que são ásperos em estreita porção basal. Extremidades elitrais cortadas em curva com espinho longo, externo e projeção curta no ângulo sutural.

Fêmures pretos, deprimidos no pedúnculo junto aos trocanteres e esparsamente pubescentes. Tíbias e tarsos pretos. Metatíbias carenadas no lado externo. Face ventral do corpo preta e com pubescência não muito densa.

Dimensões mm, holótipo macho. Comprimento total, 10,4; comprimento do protórax, 2,3; maior largura do protórax, 1,5; comprimento do élitro, 7,0; largura umeral, 2,4

Material-tipo. Holótipo macho, BRASIL, Rondônia: Ariquemes (62 km SW, "near" Fazenda Rancho Grande), 8-20.XI.1994, J. E. Eger col., black light trap (MZSP).

Discussão. Tropidion una sp. nov. é discriminada na chave publicada por Martins \& Galileo in Martins (2007) com
T. fernandezi (Joly, 1991) e T. pubicolle (Martins \& Napp, 1985) pelo pronoto com pubescência, élitros pretos com as duas metades com o mesmo colorido, com manchas e faixas e extremidades com espinho externo. Difere de ambas pela pubescência pronotal que, em T. fernandezi, está organizada em duas faixas largas da base ao ápice e, em T. pubicolle, praticamente reveste toda a superfície.

\section{Tropidion zonapterum (Martins, 1962)}

Ibidion zonapterum Martins, 1962: 299, fig. 28.

Tropidion zonapterum; Martins 1968: 379, est. 11, fig. 1; Martins \& Galileo in Martins, 2007: 172 (rev.).

A espécie está assinalada no Brasil (São Paulo - localidade-tipo, Goiás, Distrito Federal e Mato Grosso) e na Bolívia (Santa Cruz de La Sierra).

Material examinado (novos registros). BRASIL. Mato Grosso: Rondonópolis, fêmea, 4.X.1990, M. T. Tavares col. (MZSP). Tocantins: Paranã (Faz. Caldas, $12^{\circ} 56^{\prime}$ S, $\left.47^{\circ} 57^{\prime} \mathrm{W}\right)$, macho, 13.X.2004, R. R. Silva \& B. H. Dietz col. (MZSP).

\section{Dodecaibidion bolivianum sp. nov.} (Fig. 5)

Etimologia. Epíteto refere-se ao país de origem.

Cabeça preto-acastanhada. Fronte com pubescência moderadamente densa. Porção anterior do vértice microesculturada e com carínulas; parte posterior microesculturada com pubescência. Lobos oculares superiores com quatro fileiras de omatídios. Antenas avermelhadas atingem as extremidades dos élitros na base do antenômero IX. Escapo subcilíndrico, liso, com pubescência escassa no lado interno e na base. Antenômero III carenado, mais longo que o IV; franja interna de pelos muito longos. Antenômero XII tão longo quanto o XI.

Protórax preto-acastanhado. Pronoto com pubescência mais evidente no adelgaçamento basal. Partes laterais do protórax pubescentes, menos junto à orla anterior. Prosterno pubescente na metade posterior. Cavidades coxais anteriores fechadas atrás. Escutelo acastanhado com pubescência esparsa.

Élitros acastanhados com faixa avermelhada, estreita, ao longo da sutura. Cada élitro com duas manchas amareladas: uma elíptica, dorsal, pouco antes do meio; outra oblíqua, dorsal, no terço apical. Pelos elitrais longos, organizados em quatro fileiras longitudinais, três dorsais e uma lateral; pontuação de interestria praticamente ausente. Ápices dos élitros cortados em curva com espinho curto no ângulo interno e ângulo externo largo e arredondado.

Fêmures acastanhados com bases mais avermelhadas. Tíbias e tarsos avermelhados. Metatíbias sem carena. Esternos torácicos acastanhados com pubescência serícea. Urosternitos mais avermelhados em pubescência rala.

Dimensões mm, holótipo fêmea. Comprimento total, 7,0; comprimento do protórax, 1,6; maior largura do protórax, 1,0; comprimento do élitro, 4,7; largura umeral, 1,2. 
Material-tipo. Holótipo fêmea, BOLIVIA, Santa Cruz: Prov. Florida (Refugio Los Volcanes, 4 km N Bermejo, 1806' S, 63³6' W, 1045-1200 m), 28.X - 5.XI.2007, S. W. Lingafelter col., mv/uv lights (MNKM).

Discussão. Dodecaibidion bolivianum sp. nov. assemelha-se a $D$. modestum Martins, 1970, cujos tipos já foram devolvidos para o MNHN o que impede uma comparação mais apropriada. As distinções entre as espécies foram baseadas na descrição em Martins (1970: 993, fig. 511). Dodecaibidion modestum tem fronte provida de sulcos longitudinais na metade superior; o escapo é apenas deprimido no lado superior da base; pronoto tem tubérculos láterobasais; mancha amarelada posterior dos élitros é soldada à margem e existe uma terceira mancha, muito pequena, no quarto apical. Em D. bolivianum, a fronte não tem sulcos; o escapo não tem depressão basal; o pronoto não tem gibosidades; a mancha amarelada do terço apical dos élitros não alcança a sutura e não existe uma terceira mancha.

\section{Pygmodeon maculatum sp. nov.}

(Fig. 6)

Etimologia. Latim, maculatum $=$ com manchas, manchado.

Cabeça preto-avermelhada. Fronte lisa e brilhante no meio, fina e esparsamente pubescente superior e inferiormente. Vértice com alguns pontos rasos entre os lobos oculares superiores e os tubérculos anteníferos. Lobos oculares superiores com quatro fileiras de omatídios, tão distantes entre si quanto o dobro da largura de um lobo. Tubérculos anteníferos projetados com ápices aguçados.

Antenas avermelhadas atingem as extremidades dos élitros aproximadamente no ápice do antenômero VII. Escapo subcilíndrico sem sulco basal e glabro; pontuação muito rasa e esparsa. Antenômero III não carenado, mais longo do que o seguinte; IV mais curto do que o III e o V. Antenômero $\mathrm{XI}$ mais curto do que o $\mathrm{X}$.

Protórax preto-avermelhado no dorso. Pronoto com tubérculo central bem projetado especialmente se visto de perfil; pubescência serícea esparsa e mais agrupada na constrição basal e muito esparsa, pouco visível atrás do tubérculo. Partes laterais do protórax pubescentes na base e numa faixa estreita no limite com o prosterno da base ao terço anterior. Prosterno avermelhado, glabro e finamente rugoso em sentido transversal na metade anterior. Cavidade coxais anteriores abertas atrás.

Escutelo com pubescência branca, densa. Élitros pretos. Cada um com duas manchas amarelo-esbranquiçadas: uma situada no meio da metade anterior, arredondada no lado sutural, sem atingir a sutura, e toca a margem no lado externo; outra, uma faixa oblíqua em sentido descendente da sutura para a margem pouco atrás do meio. Pontuação elitral restrita aos pontos pilíferos organizados em quatro fileiras longitudinais por élitro, três dorsais e uma lateral. Ápices com espinho curto no lado sutural e espinho longo e esbelto no lado externo.
Fêmures avermelhados, glabros, pedunculados e com clava esbelta. Tíbias e tarsos avermelhados. Metatíbias não carenadas. Esternos torácicos avermelhados e pubescentes, menos no centro do mesosterno e do metasterno. Urosternitos preto-avermelhados e pubescentes.

Dimensões mm, holótipo fêmea. Comprimento total, 11,8; comprimento do protórax, 2,5; maior largura do protórax, 1,5; comprimento do élitro, 7,9; largura umeral, 2,2.

Material-tipo. Holótipo fêmea, BOLÍVIA, Santa Cruz; Província Florida: Refugio Los Volcanes, 4 km N Bermejo, 1806' S, 63³6’ W, 1045 1200 m), 28.X - 5.XI.2007, S. W. Lingafelter col., mv/uv lights (MNKM).

Discussão. Pygmodeon maculatum sp. nov., pela chave para as espécies sul-americanas publicada por Martins (2009: 141) é discriminada com $P$. m-littera (Martins, 1962) e $P$. puniceum Martins, 1970. O padrão de colorido dos élitros com duas áreas brancas e o tubérculo pronotal são semelhantes aos de P. puniceum originalmente descrita do Equador. Pygmodeon maculatum difere de P. puniceum: colorido corporal preto-avermelhado e extremidades elitrais biespinhosas. Em P. puniceum, o colorido corporal é alaranjado e os ápices dos élitros têm só os espinhos externos.

\section{Compsibidion elianae sp. nov.}

\section{(Fig. 7)}

Etimologia. O epíteto é uma homenagem a Eliana Marques Cancello (MZSP) coletora do holótipo.

Cabeça castanho-avermelhada, escura. Fronte com a sutura frontal bem demarcada, lisa na metade inferior e finamente pontuada na metade superior. Vértice (40x) microesculturado com pilosidade esparsa atrás dos lobos oculares superiores. Tubérculos anteníferos projetados. Lobos oculares superiores com quatro fileiras de omatídios.

Antenas castanho-avermelhadas nos antenômeros basais e mais avermelhada para as extremidades; alcançam as pontas dos élitros no meio ou no ápice do antenômero IX. Escapo piriforme com sulco no lado superior da base. Antenômero III carenado e sulcado longitudinalmente no meio; comprimento maior do que o do IV. Antenômero IV subigual ao V em comprimento; lado interno dos flagelômeros basais com pelos curtos e muito esparsos.

Protórax castanho-avermelhado, com lados bem abaulados no centro. Pronoto com cinco tubérculos: dois láteroanteriores; um central, longitudinal e dois látero-basais mais afastados entre si do que os látero-anteriores. Pubescência pronotal reveste toda a superfície, menos no topo do tubérculo central. Partes laterais do protórax pubescentes menos no terço anterior. Prosterno pubescente na metade posterior.

Escutelo densamente pubescente. Élitros castanhoavermelhados com grande mancha amarelada que vai do sétimo basal até logo depois do meio; o limite dessa mancha com o terço apical é transversal; a mancha é reticulada por transparência. Pontuação elitral constituída por pontos ásperos ao redor do escutelo que se prolongam contíguos à sutu- 
ra por pequena extensão; pontos normais, contíguos à sutura prolongam-se até o ápice; contam-se ainda três fileiras de pontos, duas dorsais e uma, indistinta, lateral. Extremidades dos élitros truncadas com espinho externo.

Fêmures avermelhados. Abas apicais dos meso- e metafêmures acuminadas e subiguais. Tíbias e tarsos castanhoavermelhados. Metatíbias carenadas no lado externo. Face ventral do corpo avermelhada. Esternos torácicos densamente pubescentes. Urosternitos avermelhados com pubescência mais esparsa.

Dimensões mm, respectivamente holótipo fêmea/parátipo fêmea. Comprimento total, 17,4/15,7; comprimento do protórax, 3,8/3,4; maior largura do protórax, 3,0/2,6; comprimento do élitro, 12,1/11,1; largura umeral, 4,2/3,4.

Material-tipo. Holótipo fêmea e parátipo fêmea, BRASIL, Goiás: Goiânia (Campus da Universidade Federal de Goiás), 25.X.2003, E. M. Cancello col. (MZSP).

Discussão. O aspecto geral de Compsibidion elianae sp. nov. lembra muito o de C. quadrisignatum (Thomson, 1865) e chegamos a cogitar de uma variação de cor. Entretanto, diversos caracteres a distinguem de C. quadrisignatum: região entre os tubérculos anteníferos sem pubescência; escapo acentuadamente piriforme; lado interno dos flagelômeros basais com pelos curtos e muito esparsos; lados do protórax com forte projeção arredondada no meio; cada élitro com única mancha amarelada; limite posterior da mancha amarelada no nível do terço apical; espinhos das extremidades dos élitros avermelhados; metasterno inteiramente revestido por pubescência. Em C. quadrisignatum: região entre os tubérculos anteníferos, pubescente; escapo piriforme-alongado; lado interno dos flagelômeros basais com pelos densos e longos; lados dos protórax praticamente sem projeção no meio; cada élitro com duas manchas amareladas; limite posterior da mancha amarelada do terço apical próximo do quarto apical; centro do metasterno sem pubescência.

\section{Compsibidion novalimae sp. nov.}

(Fig. 8)

Etimologia. Nome específico é referente a Nova Lima, cidade do estado de Minas Gerais, onde foi coletado o holótipo.

Cabeça avermelhada. Fronte finamente pontuada entre os tubérculos anteníferos. Vértice (40x) microesculturado com alguns pontos pequenos. Lobos oculares superiores estreitos com quatro fileiras de omatídios. Tubérculos anteníferos projetados, separados e não aguçados.

Antenas avermelhadas atingem as pontas dos élitros na extremidade do antenômero IX aproximadamente. Escapo gradualmente engrossado para o ápice, com sulco raso na base. Antenômero III carenado, mais longo do que o IV, com franja interna esparsa. Antenômero IV mais curto do que o V.

Protórax cilíndrico, com lados retos, sem projeções. Pronoto sem tubérculos com duas faixas de pubescência lon- gitudinais da base até o ápice. Partes laterais do protórax com pubescência na base. Prosterno com faixas de pubescência das procoxas até o meio; entre elas o prosterno é glabro.

Escutelo revestido por pubescência branca e densa. Élitros avermelhados. Cada um com duas manchas amareladas e transparentes: uma grande, do sexto basal até o meio, aproxima-se, mas não toca a sutura; outra ocupa o terço apical e toca o friso sutural. Pontuação elitral restrita aos pontos pilíferos que se organizam, no meio de cada élitro, em cinco fileiras longitudinais: três dorsais e duas laterais. Ápices dos élitros obliquamente truncados e desarmados.

Fêmures avermelhados e pubescentes. Ápices dos mesoe metafêmures com abas apicais aguçadas e não projetadas. Tíbias e tarsos mais amarelados. Face ventral do corpo avermelhada. Metasterno esparsamente pubescente com centro-posterior glabro. Urosternitos pubescentes.

Dimensões mm, respectivamente holótipo fêmea/parátipo fêmea. Comprimento total, 8,5/11,3; comprimento do protórax, 1,8/2,3; maior largura do protórax, 1,2/1,6; comprimento do élitro, 5,9/7,8; largura umeral, 1,9/2,5.

Material-tipo. Holótipo fêmea, BRASIL, Minas Gerais: Nova Lima, 21.X.1985, V. O. Becker col. (DZUP). Parátipo fêmea com os mesmos dados do holótipo (MZSP).

Discussão. Compsibidion novalimae sp. nov. assemelhase, pelo padrão de colorido, a C. elianae sp. nov., C. ilium (Thomson, 1864) e C. quadrisignatum (Thomson, 1865). Distingue-se de todas pelas extremidades elitrais desarmadas e por apresentar a mancha amarelada posterior ocupando todo terço apical. Nas três espécies citadas acima, os ápices dos élitros são espinhosos e a mancha posterior dos élitros não atinge os ápices (C. ilium e C. quadrisignatum) ou não existe (C. elianae).

\section{Compsibidion campestre (Gounelle, 1908)}

Octoplon campestre Gounelle, 1908: 667.

Compsibidion campestre; Martins 1969:690; Monné 2005: 346 (cat.); Martins \& Galileo in Martins, 2007: 327 (rev.).

Gnomidolon perelegans Melzer, 1933: 368.

Octoplon perelegans; Prosen 1961: 127.

Material examinado (procedências inéditas não assinaladas por Martins, 1962, 1969, 1971, 2007). BRASIL, Maranhão: Balsas. Alagoas, Piranhas (Fazenda Mecejana). Goiás: Cabeceiras (Lagoa Formosa), Caldas Novas. Minas Gerais: Santa Bárbara (Peti-CEMIG), Serra do Cipó.

\section{Compsibidion peti sp. nov.}

(Fig. 9)

Etimologia. O nome da espécie refere-se à localidade de coleta.

Cabeça castanho-avermelhada. Fronte com área elíptica inferior bem delimitada; lados com carena longitudinal; metade superior pontuada $(40 \mathrm{x})$ e esparsamente pubescente. Tubérculos anteníferos projetados. Região do vértice entre os tubérculos anteníferos com superfície irregular. Lobos oculares superiores com quatro fileiras de omatídios. 

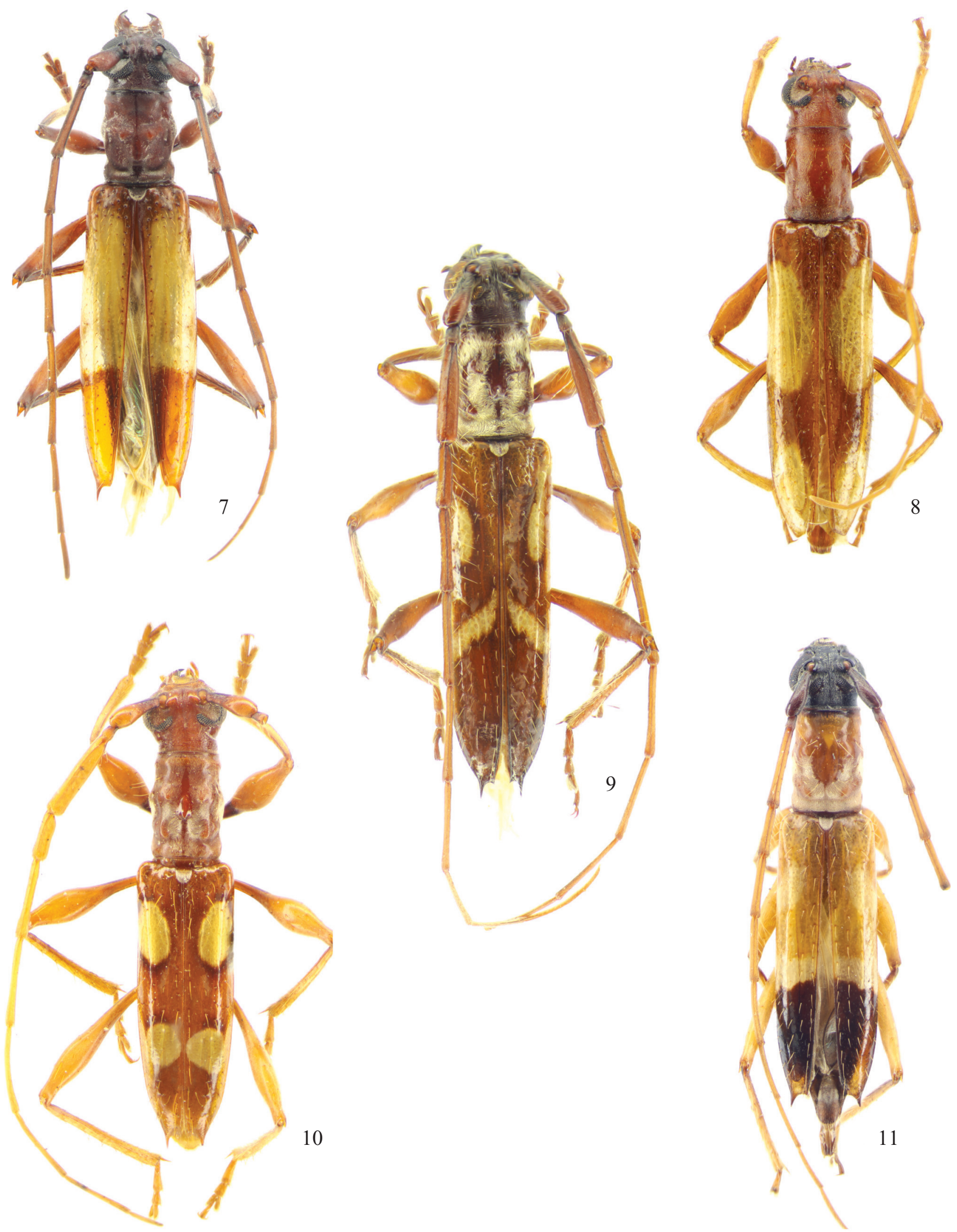

Figs. 7-11. 7. Compsibidion elianae sp. nov., holótipo fêmea, comprimento total, $17,4 \mathrm{~mm} ; 8$. Compsibidion novalimae sp. nov., holótipo fêmea, comprimento total, $8,5 \mathrm{~mm}$; 9. Compsibidion peti sp. nov., holótipo macho, comprimento, $13,7 \mathrm{~mm} ; 10$. Compsibidion ybyra sp. nov., holótipo macho, comprimento, $10,8 \mathrm{~mm}$; 11. Compsibidion manauara sp. nov., holótipo fêmea, comprimento, 12,4 mm. 
Antenas avermelhadas atingem as extremidades elitrais no ápice do antenômero VII. Escapo gradualmente engrossado para o ápice, sulcado e escurecido no lado dorsal da base; o sulco alongado ultrapassa o meio do escapo. Antenômeros III e IV engrossados. Antenômero III carenado com o dobro do comprimento do IV. Antenômero IV bem menos engrossado, carenado e mais curto que o V.

Protórax castanho-avermelhado. Pronoto com cinco tubérculos: dois látero-anteriores, um central e dois basais. Pubescência pronotal esbranquiçada deixa desnuda a parte central da orla anterior até o adelgaçamento basal e duas faixas longitudinais no lado externo dos tubérculos. Partes laterais do protórax desnudas. Prosterno com duas faixas de pubescência da base ao meio.

Élitros avermelhados com o sexto apical acastanhado. Cada um com duas manchas amareladas: uma elíptica, no meio da metade anterior, alongada, dorsal, bordejada, estreita e ligeiramente, por um avermelhado mais escuro; outra, no meio, oblíqua em sentido descendente da sutura para a margem, bordejada anteriormente por avermelhado mais escuro; para trás da faixa os élitros são de um avermelhado mais escuro. Meio de cada élitro com cinco fileiras longitudinais de pontos pilíferos: três dorsais e duas laterais. Ápices dos élitros cortados em curva com espinho externo e projeção no ângulo sutural.

Fêmures avermelhados. Pontas dos metafêmures com abas aguçadas. Tíbias avermelhadas. Metatíbias carenadas. Esternos torácicos avermelhados e pubescentes, menos no centro-posterior do metasterno. Urosternitos I e II avermelhados; III-V castanho-avermelhados.

Dimensões mm, holótipo macho. Comprimento total, 13,7; comprimento do protórax, 3,1; maior largura do protórax, 2,2; comprimento do élitro, 9,3; largura umeral, 2,9.

Material-tipo. Holótipo macho, BRASIL, Minas Gerais: Santa Bárbara (Peti-CEMIG), 23.X.1987, A. B. Machado col. (MZSP).

Discussão. Compsibidion peti sp. nov. é muito semelhante a C. campestre (Gounelle, 1908) que também ocorre nessa localidade. Compsibidion peti difere de C. campestre por não apresentar, nos élitros, a mancha apical amarelada. Em C. campestre as extremidades dos élitros são enegrecidas. As manchas dos élitros também são menores em $C$. peti: a anterior é estreita e perfeitamente dorsal, isto é, distante tanto da margem quanto da sutura ao passo que em $C$. campestre está fundida com a margem. A faixa oblíqua é muito mais estreita e mais oblíqua. Observamos também uma diferença na forma dos ápices dos élitros onde o espículo sutural é mais evidente.

Compsibidion peti também poderia ser comparada com C. ilium (Thomson, 1864) que tem a mesma fórmula antenal, colorido geral avermelhado com duas manchas amareladas em cada élitro. C. peti distingue-se: pelas extremidades dos élitros escurecidas; pelas manchas elitrais anteriores elípticas, dorsais e discretamente bordejadas de colorido mais escuro e pela faixa central oblíqua. Em C. ilium as manchas amareladas atingem a margem, são muito mais desenvolvidas e não estão bordejadas por colorido mais escuro e a central é mais com aspecto de mancha.

\section{Compsibidion ybyra sp. nov.}

(Fig. 10)

Etimologia. Tupi, ybira = irmão; alusivo a semelhança com Compsibidion ilium.

Martins (1969: 693, fig. 380) e Martins \& Galileo in Martins (2007: 303, fig. 309) consideram esta espécie como variedade cromática de Compsibidion ilium exemplares procedentes do Mato Grosso (Chapada dos Guimarães e Utiariti). As figuras no trabalho de Martins \& Galileo in Martins (2007) estão equivocadas e devem ser corrigidas como indicado acima.

Examinamos agora mais três exemplares que comprovam ser as diferenças de padrão de colorido constantes e diferentes de C. ilium. Além disso, C. ilium habita a Mata Atlântica desde a Bahia à Santa Catarina e o material-tipo de C. ybyra sp. nov. procede de Mato Grosso e da Bolívia.

Gounelle (1908) citou C. ilium para Goiás: Jataí e Joly (1991) para a Venezuela, Amazonas: Puerto Ayacucho, ambas as procedências podem estar equivocadas e devem ser confirmadas.

C. ilium foi minuciosamente descrita em Martins (1969: 693 ) e ilustrado a cores na estampa 22, fig. 21). Por isso, restringimos a descrição de C. ybyra aos caracteres diferenciais.

Tubérculos látero-anteriores do pronoto algo mais projetados. Manchas amareladas dos élitros mais regularmente arredondadas, as anteriores e as centrais não tocam a margem, não têm bordas irregulares e estão bordejadas por estreita orla mais escurecida; os espinhos apicais não são enegrecidos. Em C. ilium os tubérculos látero-anteriores são menos projetados; as manchas elitrais são maiores não estão bordejadas por colorido mais escuro e têm bordas anterior e posterior irregulares: as mais anteriores aproximam-se mais da base dos élitros e as apicais do ápice elitral.

Dimensões $\mathrm{mm}$, respectivamente holótipo macho/ parátipos fêmea. Comprimento total, 10,8/9,5-9,7; comprimento do protórax, 2,7/2,1-2,4; maior largura do protórax, 1,8/1,5-1,8; comprimento do élitro, 6,9/6,3-7,5; largura umeral, 2,2/2,1-2,5.

Material-tipo. Holótipo macho, BRASIL, Mato Grosso: Sinop (BR 153, km 500-600, $12^{\circ} 31^{\prime}$ 'S, 55³7'W, 350 m), X. 1976, Roppa \& Alvarenga col. (MNRJ). Parátipos, mesmos dados do holótipo, fêmea (MZSP); Chapada dos Guimarães, macho, Acc. 2966 (CMNH); Utiariti (Rio Papagaio), fêmea, 1-12.XI.1966, Lenko \& Pereira col. (MZSP). BOLÍVIA, Santa Cruz: Buena Vista (3,7 km SSE, Hotel Flora \& Fauna, 430 m), macho, 16-22.XI.2001, M. C. Thomas \& B. K. Dozier col.,"blacklight trap, tropical transition Forest" (MNKM).

\section{Compsibidion manauara sp. nov.}

(Fig. 11)

Etimologia. Manauara = habitante de Manaus, localidade-tipo.

Cabeça preta. Fronte com carena a cada lado do côndilo antenal até o clípeo; pubescência fina e esparsa, principal- 
mente, na metade superior. Vértice com o mesmo tipo de pubescência. Lobos oculares superiores com quatro fileiras de omatídios. Tubérculos anteníferos projetados, mas não aguçados. Antenas alcançam as extremidades elitrais na extremidade do antenômero VIII. Escapo muito pouco alargado para o ápice, com sulco basal. Pedicelo preto-avermelhado. Flagelômeros amarelados. Antenômero III carenado, mais longo do que o IV, com franja de pelos tão longos quanto aproximadamente o dobro da largura do artículo. Antenômero IV mais curto que o V.

Protórax alaranjado. Pronoto com cinco tubérculos arredondados no topo: dois látero-anteriores, um central e dois látero-basais; pubescência esbranquiçada reveste internamente os tubérculos basais, até pouco antes do meio e ocupa todo adelgaçamento basal; restante da superfície pronotal muito lisa com apenas alguns pontos crateriformes e pilíferos. Partes laterais do protórax com pubescência em parte da metade basal. Prosterno com pubescência em "V" da base ao meio.

Escutelo revestido por pubescência esbranquiçada densa. Élitros com a metade anterior alaranjada e a posterior preta. Cada élitro com duas manchas esbranquiçadas e pouco contrastantes: uma oblíqua em sentido descendente da sutura para a margem na metade anterior que não toca a sutura, mas se aproxima da margem; a outra, uma faixa praticamente transversal da sutura até a margem, situada no meio. As extremidades não apresentam mancha esbranquiçada. Pelos organizados no meio de cada élitro em quatro fileiras longitudinais; pelos moderadamente alongados. Ápices dos élitros com espinho externo e curtíssima projeção no ângulo sutural.

Fêmures amarelados. Aba interna do ápice dos mesofêmures apenas aguçadas. Pontas dos metafêmures com dois espinhos curtos e subiguais. Tíbias e tarsos amarelados.

Esternos torácicos amarelo-alaranjados e pubescentes, menos o centro do metasterno. Urosternito I amareloalaranjado escurecido no meio do ápice. Urosternitos II-V acastanhados.

Dimensões mm holótipo fêmea. Comprimento total, 12,4; comprimento do protórax, 3,0; maior largura do protórax, 2,0; comprimento do élitro, 8,2; largura umeral, 2,6.

Material-tipo. Holótipo fêmea BRASIL, Amazonas: Manaus [60 km N, Reserva PDBFF (projeto Diversidade Biológica em Fragmento Florestal, Reserva 1112)], 21.VIII.1984, B. Klein col., armadilha de Malaise (INPA).

Discussão. Compsibidion manauara sp. nov. pertence a um grupo de espécies que foi discriminado por Martins \& Galileo in Martins (2007) na sua chave para espécies do gênero no item 45: C. concisum Napp \& Martins, 1985, C. graphicum (Thomson, 1867) e C. punga Martins \& Galileo, 2007. Essas espécies têm élitros com a metade anterior avermelhada ou alaranjada e metade apical preta, têm a pubescência do pronoto organizada em forma de "V" e cobre, no máximo, os tubérculos anteriores. Como Compsibidion manauara não tem mancha clara na metade apical dos élitros, seria discriminada com $C$. concisum, descrita da
Bahia, Minas Gerais e Espírito Santo. Distingue-se de $C$. concisum: protórax alaranjado; mancha clara anterior dos élitros oblíqua; faixa central clara dos élitros quase transversal; pronoto com cinco tubérculos; pubescência esbranquiçada na parte interna dos tubérculos basais, até pouco antes do meio e em todo adelgaçamento basal; quatro fileiras de pelos nos élitros. Em C. concisum protórax castanho-avermelhado escuro; mancha clara anterior dos élitros é longitudinal e está bordejada por acastanhado; faixa central dos élitros tem contornos bem irregulares e é bem oblíqua; pronoto com quatro tubérculos; pubescência pronotal ultrapassa o meio e três fileiras de pontos pilíferos em cada élitro.

\section{Compsibidion rubricolle Melzer, 1935 stat. nov.}

Octoplon antennatum var. rubricolle Melzer, 1935: 176.

Compsibidion graphicum var. (?) rubricolle; Martins 1969: 739; Monné 2005: 348 (cat.); Martins \& Galileo in Martins, 2007: 317 (rev.).

Cabeça preta. Antenas (macho) atingem as pontas dos élitros na extremidade do antenômero VIII; das fêmeas, na ponta do X. Escapo preto-avermelhado com sulco basal. Antenômeros III-XI avermelhados.

Protórax avermelhado. Pronoto com cinco gibosidades, duas látero-anteriores muito pouco salientes; uma central pouco elevada e duas látero-posteriores mais evidentes; pubescência serícea situada adiante dos tubérculos láterobasais. Lados do protórax com pubescência na base. Prosterno com uma faixa de pubescência adiante de cada procoxa e prolongada até o meio.

Élitros avermelhados na metade anterior e pretos na posterior. Cada um com duas áreas branco-amareladas: uma faixa estreita, dorsal, no meio da metade anterior; uma faixa oblíqua em sentido descendente da sutura para a margem, no meio. Extremidades sem mancha clara. Pelos organizados no meio de cada élitro em cinco fileiras longitudinais, três dorsais e duas laterais. Ápices dos élitros com espinho externo.

Pro- e mesofêmures avermelhados às vezes com ápice mais escuro; metafêmures pretos com base avermelhada. Tíbias preto-avermelhadas. Esternos torácicos avermelhados. Urosternitos pretos.

Dimensões $\mathrm{mm}$ holótipo macho/fêmeas. Comprimento total, 10,0/7,2-11,1; comprimento do protórax, 2,5/1,8-2,5; maior largura do protórax, 1,5/1,1-1,8; comprimento do élitro, 6,5/4,9-7,2; largura umeral, 2,0/1,6-2,5.

Material-tipo. Holótipo macho, BRASIL, Rio Grande do Sul: Porto Alegre, 7.II.1933, P. Buck col. (MZSP). Parátipos - Rio Grande do Sul: Porto Alegre, 2 machos, 26.I.1933 e 13.II.1933; 5 fêmeas, 26.I.1933, 31.I.1933; 7.II.1933 (2), 10.II.1933. P. Buck col. (MZSP).

Melzer (1935) baseou a descrição em 10 exemplares: um cótipo na coleção Buck (hoje MAPA) e holótipo (= typus) e oito cótipos na Coleção Melzer (hoje MZSP). Zikán \& Wygodzinsky (1948) citaram sete "cótipos" (= parátipos). Portanto, um dos cótipos não foi localizado. Martins \& 
Galileo in Martins (2007) declararam que a etiqueta do holótipo "não tem etiqueta de procedência" o que é um equívoco (vide acima).

Material examinado. BRASIL, Rio Grande do Sul: Pareci Novo, fêmea, 14.II.1923, P. Buck col.; fêmea, 15.XI.1964, P. Buck col.; Porto Alegre, 24.X.1945, P. Buck col. (MZSP).

Discussão. Uma variedade de C. graphicum foi descrita por Melzer (1935) como var. rubricollis procedente do Rio Grande do Sul. Esta variedade é uma espécie válida cuja mudança de status é proposta. Compsibidion rubricolle distingue-se de C. graphicum pelo colorido do protórax e pela ausência de mancha clara da metade anterior dos élitros junto da margem. Em C. graphicum, o pronoto é preto com faixa basal amarelada e a metade anterior dos élitros tem mancha clara.

\section{Heterachthes tysiphonis (Thomson, 1867)}

Ibidion (Brydaeon) tysiphonis Thomson, 1867: 137.

Compsa tisiphone; Gemminger \& Harold 1872: 2832 (cat.).

Ibidion tysiphone; Thomson 1878: 6 (tipo).

Heterachthes tisiphonis; Martins 1964: 137.

Heterachthes tysiphonis; Martins 1970: 1227; Monné 2005: 374 (cat.); Martins 2009:185 (rev.).

Heterachthes decipiens Bates, 1870: 303; Martins 1964: 137 (sin).

Espécie bem variável cromaticamente ou conjunto de espécies semelhantes o que será elucidado quando material abundante puder ser examinado. O tubérculo pronotal é sempre muito desenvolvido e único e as antenas dos machos com artículos III-VI com engrossamento pouco notável.

A forma típica tem tubérculo central do pronoto único e colorido geral preto ou castanho-escuro com três manchas brancas nos élitros: uma no meio da metade basal, oblíqua em sentido descendente da margem para a sutura que não alcança; no meio, uma faixa oblíqua em sentido inverso e contínua da margem até a sutura e uma pequena que ocupa os ápices.

Martins (2009) chamou atenção para exemplares da Bolívia: Santa Cruz que tem a região elitral da base até o meio avermelhada, mas que concordam no restante dos caracteres com a forma típica.

Examinamos agora uma pequena fêmea do Peru que tem as duas metades dos élitros avermelhadas e que tem as mancha brancas estreitamente bordejadas de castanho: na anterior em todo perímetro e na faixa central na parte anterior. Essa fêmea é proveniente do Peru, Loreto: $160 \mathrm{~km}$ NE Iquitos (Explornapo Camp, Río Sucusari, 2 km do Río Napo), 2731.VIII.1992, P. Skelley col., "at night" (ACMS).

Esta fêmea não pode ser confundida com Heterachthes mucuni Martins \& Galileo, 1999 (Martins \& Galileo 1999: 306 , fig. 5) pelo pronoto sem tubérculo central e pelas manchas dos élitros mais oblíquas. Tão pouco se confundirá com H. figuratus Martins, 1970 que também tem tubérculo desenvolvido no centro do pronoto, por esse mesmo pronoto pubescente, com cinco tubérculos e sem mancha clara nos ápices dos élitros. Também difere de H. lemniscus Martins, 1970 pelo pronoto sem tubérculos com pubescência esparsa junto à base e pelo desenho dos élitros com única mancha branca no quarto apical.

\section{Kolonibidion Martins, 2009}

Kolonibidion Martins, 2009: 77; Monné \& Bezark 2009: 100 (checklist).

Algumas espécies de Compsibidion têm metafêmures engrossados e, por esse caráter, deveriam ser transferidas para Kolonibidion. Mas suas cavidades procoxais são estreitamente abertas o que as conserva em Compsibidion. Essas espécies são: C. circunflexum Martins, 1971 e C. crassipede Martins, 1971.

\section{Kolonibidion femoratum (Martins, 1971)}

Compsibidion femoratum Martins, 1971: 1457, fig. 706; Cabrera \& Fernández 2000: 35 (holótipo); Monné 2005: 348 (cat.).

Kolonibidion femoratum; Martins 2009: 78, fig. 89; Martins et al. 2009: 238 (distr.).

A distribuição de Kolonibidion femoratum é ampla. A espécie foi originalmente descrita da Argentina (Chaco) e do Mato Grosso do Sul. Foi assinalada para a Bolívia (Martins 2009: 78) e para o Maranhão (Martins et al. 2009).

Material examinado (novo registro). BRASIL, Paraíba: São João de Cariri, M. A. B. Gusmão col. (MZSP).

\section{Minibidion captiosus nomen novum}

Minibidion bicolor Martins, Galileo \& Limeira-de-Oliveira, 2011 non Minibion bicolor Martins, Galileo \& Limeira-de-Oliveira, 2009.

Duas espécies diferentes foram descritas com o mesmo nome e, portanto, a mais recente deve receber um nome novo. Minibidion captiosus distingue-se de M. bicolor principalmente pela presença de pubescência serícea organizada numa faixa transversal na base do pronoto. Ambas as espécies foram descritas do Maranhão, Caxias (Morro do Alecrim, Campus da Universidade Estadual do Maranhão).

\section{AGRADECIMENTOS}

A James Wappes (ACMS) pela doação do holótipo de Tropidion una para o MZSP; Dilma Solange Napp (DZUP), Luis José Joly (MIZA) e Augusto Loureiro Henriques (INPA) pelo empréstimo de material para estudo; a Miguel A. Monné pelo alerta da homonímia de Minibidion bicolor Martins et al., 2011; a Eleandro Moysés, bolsista IC/CNPq/FZB (Museu de Ciências Naturais, Fundação Zoobotânica do Rio Grande do Sul) pelas fotografias e tratamento digital. Ao CNPq e FAPEAM pelo auxílio financeiro ao Programa de Apoio a Núcleos de Excelência (Pronex) projeto "Amazonas: diversidade de insetos ao longo de suas fronteiras (Processo 1437/ 207)" coordenado por José Albertino Rafael (INPA). 


\section{REFERÊNCIAS}

Bates, H. W. 1870. Contributions to an insect fauna of the Amazon Valley (Coleoptera: Cerambycidae). The Transactions of the Entomological Society of London 1870: 243-335.

Cabrera, N. \& L. A. Fernández. 2000. Los tipo de Cerambycidae del Museo de La Plata (Insecta: Coleoptera). Revista de la Facultad de Ciencias Naturales y Museo. Serie Técnica y Didáctica 38: 33-38.

Gemminger, M. \& E. von Harold. 1872. Catalogus coleopterorum hucusque descriptorum synonymicus et systematicus. Monachii, Gummi 9: 2669-2988.

Gounelle, E. 1908. Listes des cérambycides de la région de Jatay, État de Goyaz, Brésil. Annales de la Société Entomologique de France 77: 587-688.

Joly, L. J. 1991. Sinopsis de la Tribu Ibidionini (Coleoptera, Cerambycidae) en Venezuela. Acta Terramaris 4: 1-84.

Martins, U. R. 1962. Ibidionini (Coleoptera, Cerambycinae) XV. Novas espécies, notas sinonímicas, redescrições. Papéis Avulsos de Zoologia 14: $267-310$.

Martins, U. R. 1964. Ibidionini (Coleoptera, Cerambycinae) XXI. Papéis Avulsos de Zoologia 16: 129-143.

Martins, U. R. 1968. Monografia da tribo Ibidionini (Coleoptera, Cerambycinae). Parte II. Arquivos de Zooogia 16: 321-630.

Martins, U. R. 1969. Monografia da tribo Ibidionini (Coleoptera, Cerambycinae). Parte III. Arquivos de Zoologia 16: 631-877.

Martins, U. R. 1970. Monografia da tribo Ibidionini (Coleoptera, Cerambycinae). Parte IV. Arquivos de Zoologia 16: 879-1149.

Martins, U. R. 1970. Monografia da tribo Ibidionini (Coleoptera, Cerambycinae). Parte V. Arquivos de Zoologia 16: 1151-1342.

Martins, U. R. 1971. Monografia da tribo Ibidionini (Coleoptera,
Cerambycinae). Parte VI. Arquivos de Zoologia 16: 1343-1508.

Martins, U. R. (org.). 2006. Cerambycidae sul-americanos (Coleoptera). São Paulo, Sociedade Brasileira de Entomologia, v. 8, 230 p.

Martins, U. R. (org.). 2007. Cerambycidae sul-americanos (Coleoptera). São Paulo, Sociedade Brasileira de Entomologia, v. 9, 350 p.

Martins, U. R. (org.). 2009. Cerambycidae sul-americanos (Coleoptera). São Paulo, Sociedade Brasileira de Entomologia, v. 10, 373 p.

Martins, U. R. \& M. H. M. Galileo. 1999. Novas espécies de Ibidionini (Coleoptera, Cerambycidae) da América do Sul. Revista Brasileira de Entomologia 43: 301-307.

Martins, U. R.; M. H. M. Galileo \& F. Limeira-de-Oliveira. 2009. Cerambycidae (Coleoptera) do Estado do Maranhão, Brasil. Papéis Avulsos de Zoologia 49: 229-247.

Melzer, J. 1933. Cerambycideos neotrópicos novos ou pouco conhecidos. Revista de Entomologia 3: 367-382.

Melzer, J. 1935. Novos cerambycideos do Brasil, da Argentina e de Costa Rica. Archivos do Instituto de Biologia Vegetal 2: 173-205.

Monné, M. A. 2005. Catalogue of the Cerambycidae (Coleoptera) of the Neotropical Region. Part I. Subfamily Cerambycinae. Zootaxa 946: 1-765.

Monné, M. A. \& L. G. Bezark. 2009. Checklist of the Cerambycidae, or longhorned wood-boring beetles, of Western Hemisphere. Rancho Dominguez, BioQuip Publications, 455 p.

Prosen, A. F. 1961. Notas sobre Ibidionini (Col., Cerambycidae). Anales del Instituto de Medicina Regional 5: 125-130.

Thomson, J. 1867. Ibidionitarum species novae. Physis Recueil d'Histoire Naturelle 1: 133-163.

Thomson, J. 1878. Typi cerambycidarum Musei Thomsoniani. Paris. E. Deyrolle, $21 \mathrm{p}$.

Zikán, W. \& P. Wygodzinsky. 1948. Catálogo dos tipos de insetos do Instituto de Ecologia e Experimentação Agrícolas. Boletim do Serviço Nacional de Pesquisas Agronômicas 4: 1-93. 